\title{
GEORGE DANIEL OLDS
}

October 14, 1853-May 10, 1931

With the death of George Daniel Olds, on May 10, 1931, the firmament of mathematical instruction lost one of its bright stars. The light he shed in and out of the classroom was always clear and steady, his guidance sure, and his influence inspiring and uplifting. Endowed with an exceptionally brilliant intellect and with a logical mind, he early became a seeker after truth. He sought to know where wisdom could be found and he seemed to discover the place of understanding. His life-long habit of reading and study brought him to a high level of attainment in a variety of fields, but mathematics was the interest nearest to his heart. It was with enthusiasm that he went abroad for graduate studies under such men as Fuchs, Quincke, Kirchoff, Helmholtz, and Weierstrass; and these masters recognized in their young American pupil a kindred spirit.

Listening to him as he taught his chosen subject, one could not fail to be impressed by the breadth of his background and the profundity of his knowledge. It became clear that he was above all a teacher, by virtue of his success in presenting mathematical truth in a manner adapted to the understanding of his students. At the same time, he imparted to them something of his own enthusiasm and love of learning.

Called in 1891 from his Alma Mater, the University of Rochester, he taught mathematics at Amherst College until 1923, when he was elected President of the College, a position which he held until his resignation in 1927. During his incumbency the duties of his office demanded an extraordinary degree of wisdom and tact, and the history of his successful administration will ever remain a worthy monument to his character and ability.

But remarkable as were his achievements as teacher and as president, it was his capacity for making friends that made him almost unique among men. During his forty years of residence in Amherst, including thirteen years as Dean of the College, the thousands who knew him would bear unanimous testimony to the justice and loyalty of George Olds, the man.

* "He had a genius for friendship; everybody felt it. There was no distinction of class, race, or color; no Town and Gown. The smile that warmed you when he greeted you, lifted you, whoever you were, to his plane, and made you an aristocrat with him. No wonder we loved him; he knighted us all with the touch of his character. His kind of friendship comes only from the deeps; it is no surface glitter. His own soul was so clear, so steadfast, so real, that he saw only those things in others. And his own steadfastness came from a strong faith, which was childlike in that it was clear-seeing and untainted, but which had for its foundation a very fine mind disciplined by training and hard work. 'Sans peur et sans reproche' - without fear because he had nothing to hide, without taint because second-rate things were crowded out by his faith, courage, and vitality. As men pass, others are called to fill their places, but what one man can we find combining his fine training, his high purpose, his humor, his friendliness, and his faith in God? He was 'a verray parfit gentil knight."'

T. C. EsTy

* From The Amherst Record. 